\title{
Biodiversity in Chestnut Woodlots: Management Regimen vs Woodlot Size
}

\author{
Javier Guitián ${ }^{1}$, Pablo Guitián ${ }^{1}$, Ignacio Munilla ${ }^{1}$, José Guitián², Josefina Garrido ${ }^{3}$, \\ Liliana Penín ${ }^{3}$, Paula Domínguez ${ }^{1}$, Luis Guitián ${ }^{4}$ \\ ${ }^{1}$ Department of Botany, University of Santiago, Santiago, Spain \\ ${ }^{2}$ Department of Celular Biology and Ecology, University of Santiago, Santiago, Spain \\ ${ }^{3}$ Department of Ecology and Animal Biology, University of Vigo, Vigo, Spain \\ ${ }^{4}$ Deparment of Geography, University of Santiago, Santiago, Spain \\ Email: javier.guitian@usc.es
}

Received July $19^{\text {th }}$, 2012; revised August 20 ${ }^{\text {th }}$, 2012; accepted September $1^{\text {st }}, 2012$

\begin{abstract}
This paper analyzes the effect of woodlot size and land-use intensity on the species richness of vascular plants, birds, beetles, and ants in Castanea sativa (chestnut) woodlots of the northwestern Iberian Peninsula included in the category "9260 Castanea sativa woodland", “Annex I, DC 92/43/European Community". The results show that the surface area of the woodlot did not affect the richness of vascular plants and ants but did affect birds and beetles. The level of abandonment of the woodlot affected only the richness of vascular plants, while the use level had no significant impact on species richness of any of the groups. The degree of maturity of the woodlot, estimated by the tree-trunk circumference, determined only the richness of plants but not that of different groups of animals. In conclusion: 1) Plants and animals responded differently to woodlot size, abandonment, and the degree of maturity of the woodlots; 2) Traditional agricultural practices do not negatively affect the biodiversity of the chestnut woodlots of the northwestern Iberian Peninsula or favor plant diversity; and 3) A traditional use of these woodlots may continue to play an important role in maintaining the diversity of plant species in the area.
\end{abstract}

Keywords: Vascular Plants; Birds; Beetles; Ants; Species Richness; Castanea Woodlands

\section{Introduction}

In changing landscapes, the spatial distribution of species depends on their biological characteristics and the pattern of land alteration. When land abandonment occurs, the difficulties in predicting the effects of landscape change on biodiversity arise from large differences in species' dispersal behavior and the unpredictability of patterns of land-use change (Veldkamp \& Lambin, 2001 and references therein). The major problems related to the abandonment of agricultural land are biodiversity loss, increased fire frequency and intensity, soil erosion and desertification, loss of cultural and/or aesthetic values, lower landscape diversity, and reduced water provision. The abandonment of agricultural land may also benefit humans, including passive revegetation and active reforestation, water regulation, soil recovery, nutrient cycling, and increased biodiversity and wilderness (see Rey Benayas et al., 2007 and references therein).

The land-abandonment process generates a mosaic of uses ranging from complete abandonment to different levels of intensity of exploitation, with potential consequences for the biological richness of these areas. The consistency of species responses to land-use changes may be altered by within-patch habitat conditions. Indeed, the degree of natural and anthropogenic disturbance at a small scale may influence species dynamics to an equal or greater extent in comparison with perturbation in a larger-scale landscape structure (Debuse et al., 2007).

Throughout most of the northwestern Iberian Peninsula, ma- ture indigenous forests (e.g., Quercus robur L., Fagus sylvatica $L$., etc.) have been intensively exploited and are currently very scarce. A common formation in this region is the chestnut (Castanea sativa Mill.) woodland, surrounding small villages and managed for sweet chestnuts and timber. This is the most important remaining deciduous woodland type in this region, and for centuries has in many respects acted as a substitute for the indigenous deciduous forests throughout most of NW Spain. Chestnut woodlands are typically comprised of large trees, many well over 200 years old, but in recent decades these forests, being traditionally exploited for feeding humans and animals, have suffered a progressive process of abandonment as a result of rural depopulation and fungal diseases. This has seriously damaged the trees and reduced crop quality (Pitte, 1986), with economic and ecological consequences (Arnaud et al., 1997).

Several authors have studied the effects that this process, and the resulting management regimes, have on the plant and animal richness in chestnut woodlands, showing a clear relationship between the two, and proposing strategies for biodiversity conservation both locally and regionally (Roberts \& Gilliam, 1995; Peltzer et al., 2000; Romane et al., 2001; Hansson, 2001; Gondard et al., 2001, 2006, 2007; Mason \& MacDonald, 2002). Also, several works have analyzed the influence of spatial characteristics (area, shape, etc.) on the richness of plants and animals in these woodlands, although the results are not always conclusive (Dzwonko \& Loster, 1992; Bastin \& Thomas, 1999; Petit et al., 2004; Cousins \& Aggemyr, 2008; Konstantinidis et al, 2008). 
In this study, we focus on four features that influence species richness in woodland patches and analyze to what extent the size and the use of chestnut woodlots affect the richness of vascular plants, birds, ants, and beetles. For this, we used the surface area of the woodland, the abandonment of the woodland in the recent past, as reflected by the structure of its vegetation, and the current use as determined by the intensity and homogeneity of chestnut harvesting. In addition, we analyzed to what degree forest maturity influences species richness of these groups. Specifically, after characterizing the woodlots and analyzing species richness of the different groups, we tried to respond to the following questions: 1) Does the surface area of the woodlot affect species richness of the different groups? 2) Does the current level of abandonment and use affect the different groups? 3) Does the degree of maturity of the woodlot affect species richness of different groups? 4) Finally, in the three cases analyzed, is the response consistent among the plant and animal groups studied?

This approach is relevant because managed chestnut woodlands are included in the Habitats Directive of Spain (Annex 1 of Directive 92/43: “Castanea sativa woodlands 9260") and several studies have shown their high ecological importance in supporting a wide variety of flora and fauna (Rodriguez-Guitián et al., 2005; González-Varo et al., 2008).

\section{Methods}

\section{The Study Area}

The study was conducted in the $\mathrm{O}$ Courel and Ancares mountains (provinces of Lugo and León, NW Spain), a highly cultivated mountain area covering roughly $500 \mathrm{~km}^{2}$. The territory is part of the Natura 2000 Network included in the "Ancares-Courel Site of Community Importance” (ES1 120001). The landscape is made up of a mosaic of small villages, farmland, and chestnut woodlots set into a matrix of thickets and woodlands dominated by Quercus, Betula, and Fagus.

\section{Woodland Characterization}

Of the approximately 100 woodlots found in the area (unpublished data), we selected 30 woodlots of different sizes and land-use intensity. The woodlands were spatially characterized by generating a series of map layers using Geomedia (Intergraph) software supported by GVSIG (free software) for areas outside the Autonomous Community of Galicia. These foundations were used to generate a geographic information system with UTM projection (zone 29), based on the European 1950 datum and in two formats (shape and mdb) that can be read by any standard geographic information system. A photo interpretation was performed to define the edges of the chestnut groves, backed by field inspection and based on the orthophoto SIXPAC of the area taken in 2002-2003.

In the woodlots, two different management levels were distinguished: the level of abandonment and the level of current use. The level of abandonment was quantified by the direct observation of the vegetation structure and by interviews with the local population and woodland owners. On the basis of the information compiled, three levels were assigned: 1 = abandoned or semi-abandoned, the land is not cleared of vegetation on a yearly basis, but nuts are gathered sporadically; 2 = moderate use, the land is cleared yearly or twice a year; and $3=$ intensive use, the land is cleared of vegetation by burning or cutting. To verify that the levels of land use assigned to the woodlands corresponded to their structural characteristics, we determined the structure of the vegetation in a sample of 16 chestnut woodlots. For this purpose, we located the central point of each woodlot with the help of an aerial photograph (Aerial photograph after 2002. SIXPAC, SIGPAC Junta Castilla y León). The slope was estimated at this point with a clinometer and the slope's orientation was determined by means of a compass. Next, four 50-m transects were randomly taken and, on each transect, five points were randomly assigned to calculate the vegetative cover index in the strata between 0 and $12 \mathrm{~m}$ (Karr, 1971). The cover index was calculated as the percentage of actual contacts out of all the possible contacts (4 transects $\times 5$ points/transect $\times 6$ strata/point). The cover indices computed on the basis of the structural data correlated significantly with the use levels estimated in the field; hence the latter indices were used in the analyses.

The current use level was quantified on the basis of the proportion of chestnuts with respect to the number of cupules present in the woodlot (spiny cupules containing 3 - 7 chestnut fruits), and the coefficient of variation; this gives an idea of whether or not the crop was collected. For this, in each woodlot, random samples were taken from 20 or 12 squares of $2 \times 0.5 \mathrm{~m}$ according to the size of the woodlot, counting the number of chestnuts and cupules present; this ratio was higher in the woodlots where the collection of chestnut fruits and consequently also its use level proved low. Similarly, the woodlots in which the current use was intensive should show strong uniformity in the degree of intervention, and therefore the coefficient of variation of the ratio chestnuts/cupules (use heterogeneity) was low; in the contrary case, the woodlands having an intermediate use level should show a higher variation coefficient.

The degree of maturity of the woodlots was estimated on the basis of the breast-height trunk circumference of the trees. For this, over the transect, every $25 \mathrm{~m}$, we situated $5 \times 5 \mathrm{~m}$ squares alternately on the left and on the right. With a measuring tape, we measured the circumference of all the trees in each square.

\section{Species Richness}

Vascular plants. To determine the number of plant species in each of the 30 woodlots, we marked a point in the center of the woodland and drew a circle with a $20-\mathrm{m}$ radius. We identified and recorded all the vascular plant species found in the area (total area sampled $3.14 \times 20^{2}=1256 \mathrm{~m}^{2}$ ). This inventory was conducted twice a year, in early spring and early summer, to make sure that all the species found in the plot site were included in the census. The area selected for the study had been previously determined by plotting a species area-curve using 5-m radius increments until reaching a value where the number of species stabilized. The total number of species was then revised based on the list of indicator species of these woodlands in the study region (see Rodriguez-Guitián, 2004; RodríguezGuitián et al., 2005, for additional information).

Birds. For the study of the composition and structure of the bird communities, a sample of 20 woodlots were chosen from those previously used, and were visited in the summer (nesting) and winter (overwintering) for 3 years (2006, 2007, and 2008). A total of 240 censuses were made (20 woodlots $\times 2$ seasons $\times$ 3 years $\times 2$ replicates), counting 2702 individuals of 39 species.

Ants. To study the ants, we used 8 woodlots in which we 
randomly drew 30-m-long transects the length of the woodlot. Along these lines, we placed 30 pitfall traps, which consisted of a plastic bottle c. $10 \mathrm{~cm}$ in diameter $\times 15 \mathrm{~cm}$ deep containing detergent surfactant so the ants would sink in the liquid. After the traps were left for $24 \mathrm{~h}$, the contents were collected in $70^{\circ}$ alcohol for preservation and subsequent identification. This sample was made in 2006 and 2007.

Beetles. In the study of the beetles, eight woodlots were sampled in an attempt to collect all the variability possible in the size and degree of use of these woodlots. In each woodlot, pitfall traps (5 - 10) were set at a given number of random points set, depending on the surface area, this constituting one of most widely used indirect techniques for studying Coleoptera populations (Ribera et al., 2001; Taboada et al., 2004). The traps used in this study consisted of a plastic bottle half filled with a liquid preservative (Propilenglicol at 25\%); the bottle measured $12 \mathrm{~cm}$ high and $8 \mathrm{~cm}$ in diameter and was buried in such a way that its mouth was higher than or flush with the soil level, while a wooden shield protected against falling plant debris. The contents were collected after approximately two weeks. Traps were set during summer and autumn of two consecutive years (2006 and 2007) at the 61 sampling points previously established. The trap contents were taken to the laboratory, preserved in $70^{\circ}$ alcohol for subsequent identification and study.

\section{Data Analysis}

Species richness was assessed by means of individual-based rarefaction (Gotelli \& Colwell, 2001), thus accounting for differences in sampling effort. Datasets were standardized to a common number of individuals (30 for birds and ants and 100 for beetles) assuming a hypergeometric sampling distribution (Heck et al., 1975).

The effects of the different variables on the total number of species were analyzed by General Linear Modeling (GLM, probability distribution Poisson, link function Logarithm). As dependent variable, the number of species of each group was used, calculating the mean for the biennial samplings. The level of abandonment was included as the factor and the rest of the predictor variables were included in the model as covariables. All of the analyses were carried out with the statistical pack SPSS v.19.

\section{Results}

\section{Characteristics of the Woodlands}

Chestnut woodlots are found at altitudes ranging from 600 to $1000 \mathrm{~s} \mathrm{~nm}$. The area of the woodlots ranged from 0.3 to 94 hectares. Some $53 \%$ of the woodlots had a low level of abandonment, the mean being $20 \%$, with $27 \%$ being abandoned. The level of current use estimated by the relationship of chestnuts/cupules varied from 0.43 for the highest use level and 2.20 for the lowest; the CV (mean/sd $\times 100$ ) of this ratio varied from 147.43 for the most heterogeneous forest to the use level of 16.36 for the most homogeneous. The circumference of the trees ranged from $36.76 \pm 52.47 \mathrm{~cm}$ in the youngest woodlot to $329.62 \pm 110.37 \mathrm{~cm}$ in the oldest woodlot.

\section{Species Richness of Different Taxa}

The number of species of plants, birds, ants and beetles in the sweet chestnut woodlots are show in Table 1.

Vascular plants. In the woodlots studied, we identified in total nearly 160 species of vascular plants. The total number of species in each woodlot ranged from 6 to 32. In addition to the chestnut, the most frequent woody species were Fraxinus excelsior and Quercus robur, present in more than $75 \%$ of the woodlands sampled, with Luzula campestris and Viola riviniana being the most common understory plants. The complete list of species appears in Guitian et al. (2012).

Birds. A total of 39 species and 2702 individuals were recorded. The most common species were robin (Erithacus rubecula), wren (Troglodytes troglodytes), and blackbird (Turdus merula) with, respectively, 14.9, 12.0, and 11.5\% of sightings. The (accumulated) total number of species per woodlot ranged from 9 to 20. When rarefied to a common number of individuals, mean species richness was 11.3 (6 - 14). (See Appendix 1 for the complete list of species)

Beetles. A total of 3.582 individuals were identified, belonging to 23 families and 78 species. Carabidae (1152 specimens), Anobiidae (974), and Staphylinidae (670) were the families with the largest number of specimens. Taking into account the number of species in each family, Staphylinidae (13 species), Carabidae (12), Curculionidae (9), and Leiodidae (7) were noteworthy. The results show that Ptinus fur (Anobiidae) was the most abundant species captured (926 specimens). The total number of species in each woodlot ranged from 10 to 28 . (See Appendix 1 for the complete list of species).

Ants. The ant samplings resulted in the identification of a total of 4078 individuals in the year 2006 and 1362 in 2007. The individuals captured corresponded to the genera Formica, Lasius, Myrmica, Tapinoma, Aphaenogaster, and Leptothorax. The most abundant species was Formica rufa. The total number of species in each woodlot ranged from 1 to 7 (See Appendix 1 for the complete list of species).

\section{Relation between Species Richness with Surface Area of the Woodlots}

The analysis showed that the surface area of the woodlot had no significant effect on vascular plant richness (Table 2), but did have an impact on the richness of birds and beetles; contrarily, no effect was found on ants (Table 2). In the first two cases, the effect was positive, so that the largest woodlands were richer in birds and beetles (Figure 1).

\section{Relationship of Species Richness with the Level of Abandonment and the Level of Current Use}

Species richness of vascular plants apparently responded to the level of abandonment but not with the level of current use, both considering the quotient chestnuts/cupules as well as its

\section{Table 1.}

Number of species of plants, birds, ants and beetles in the sweet chestnut woodlots of Caurel. $\mathrm{N}=$ number of woodlots examined. $\mathrm{SD}=$ Standard Deviation.

\begin{tabular}{ccccccc}
\hline & N & Total & Minimum & Maximun & Mean & SD \\
\hline Plants & 30 & 156 & 6 & 32 & 19.2 & 6.1 \\
Birds & 20 & 39 & 9 & 20 & 10.9 & 4.1 \\
Ants & 8 & 10 & 1 & 7 & 4.3 & 2.2 \\
Beetles & 8 & 78 & 10 & 28 & 23.4 & 6.2 \\
\hline
\end{tabular}


coefficient of variation (use heterogeneity; Table 2). As a whole, the GLM model proved to be significant $(p<.05)$ and the results show that the level of land use had a significant effect on total plant species richness, with a greater richness found in the moderate land-use level (mean 13.8, 20.5 and 19.7 for levels 1, 2, and 3 respectively).

Species richness for birds, ants, and beetles was not determined by the level of abandonment nor the level of current use estimated by the chestnuts/cupule ratio as their coefficient of variation (Table 2).

\section{Relationship between Species Richness and Forest Maturity}

Only the richness of the vascular plants showed a significant relation with woodlot maturity, in such a way that the most mature woodlot had greater species richness. This variable had no significant effect on the richness of any of the animal groups studied (see Table 2).

Table 2.

Results of GLM to analyze the effects of the different variables on the total number of plant and animal species.

\begin{tabular}{|c|c|c|c|}
\hline & Wald Chi-square & Df & $p$ \\
\hline \multicolumn{4}{|l|}{ Plant species } \\
\hline (Intersection) & 164.846 & 1 & .00 \\
\hline Abandonment & 8.742 & 2 & .01 \\
\hline Current use & .525 & 1 & .47 \\
\hline Area & .668 & 1 & .41 \\
\hline Age & 3.574 & 1 & .05 \\
\hline Current use (CV) & .094 & 1 & .76 \\
\hline \multicolumn{4}{|l|}{ Birds } \\
\hline (Intersection) & 32.381 & 1 & .00 \\
\hline Abandonment & .096 & 2 & .95 \\
\hline Current use & 2.148 & 1 & .14 \\
\hline Area & 15.406 & 1 & .00 \\
\hline Age & .853 & 1 & .36 \\
\hline Current use (CV) & .097 & 1 & .76 \\
\hline \multicolumn{4}{|l|}{ Beetles } \\
\hline (Intersection) & 4.610 & 1 & .03 \\
\hline Abandonment & .286 & 2 & .87 \\
\hline Current use & 2.821 & 1 & .09 \\
\hline Area & 3.742 & 1 & .05 \\
\hline Age & .755 & 1 & .39 \\
\hline Current use (CV) & .096 & 1 & .76 \\
\hline \multicolumn{4}{|l|}{ Ants } \\
\hline (Intersection) & 3.256 & 1 & .07 \\
\hline Abandonment & .025 & 2 & .99 \\
\hline Current use & .311 & 1 & .58 \\
\hline Area & 2.586 & 1 & .11 \\
\hline Age & .004 & 1 & .95 \\
\hline Current use (CV) & .429 & 1 & .51 \\
\hline
\end{tabular}

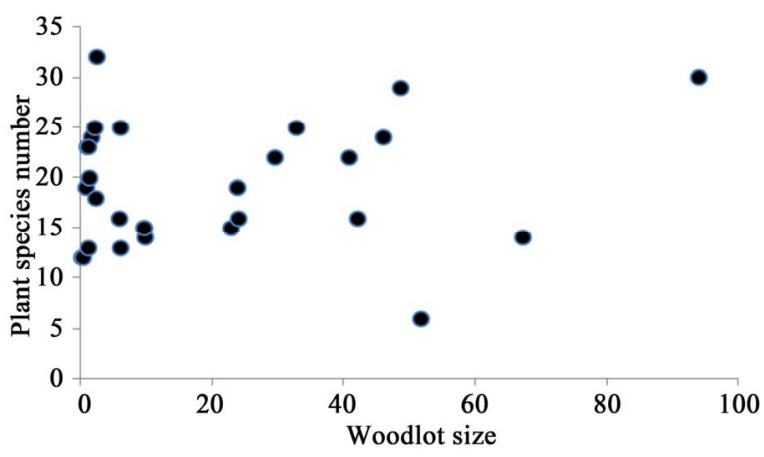

(a)

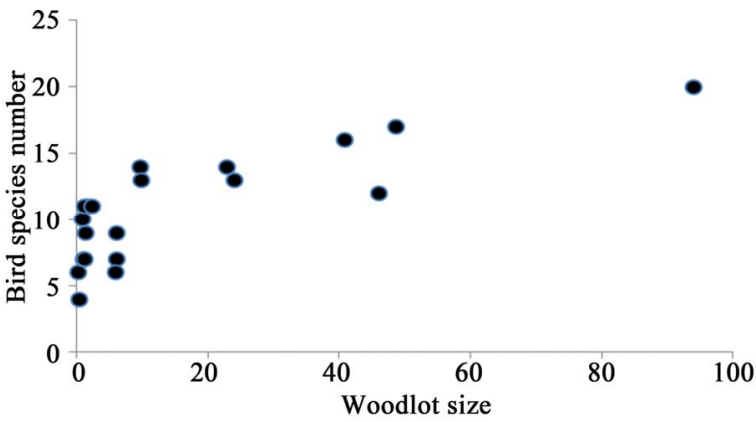

(b)

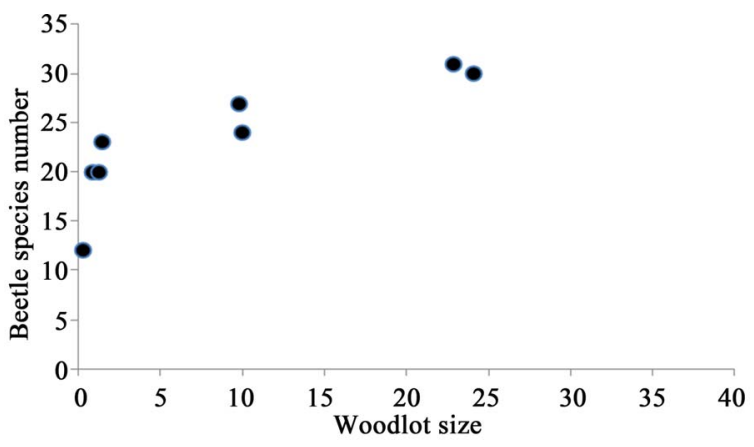

(c)

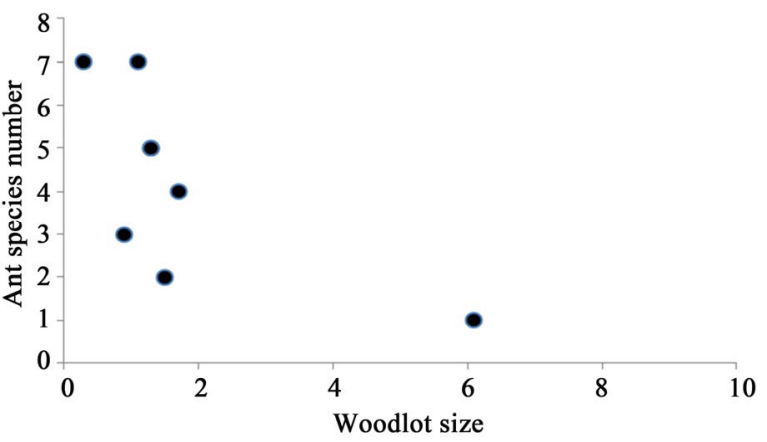

(d)

Figure 1.

Relationship between woodlot size (hectares) and species richness of different groups: (a) Vascular plants; (b) Birds; (c) Beetles; (d)Ants.

\section{Discussion}

Castanea sativa woodlands in the northwestern Iberian Peninsula vary widely in surface area and use intensity, which may 
determine both the number and abundance of plant and animal species. This variation does not appear to be related to differences in local environmental conditions, since the woodlots are generally located on deposits in areas of Quercus pyrenaica woodlands in the mountains of the western Iberian Peninsula.

In general, our results revealed major differences in species richness between woodlots, and showed that in traditionally managed woodlots, vascular plants, birds, beetles and ants, were likely to respond differently to forest-patch size, age, and abandonment.

\section{Relation of Species Richness to the Surface Area and the Use Level of the Woodlots}

Our results show that the surface area of the woodlots bore no relation to species richness of the vascular plants, in agreement with the findings of Guitián et al. (2012), but was determinant in the case of birds and beetles though not for ants. In the same geographical setting, Gonzalez Varó et al. (2008) found that woodland size was the only variable that significantly predicted the presence of breeding pairs de Sitta europaea in these forests, and that the number of pairs was strongly predicted by woodlot size; in the same sense, Baileya et al. (2002) reported evidence for patch area and composition effects: larger woodlands support more woodland bird species.

In beetles, responses have been show in several ways. Gibb and Hochuli (2002) demonstrated that the large fragments had no more species per unit of area in most of the arthropod groups, while Fujita et al. (2008) found a decline in the number of Carabidae and Brachinidae species in small fragments of forests in Japan. In the case of ants, Gibb and Hochuli (2002) indicated that small fragments were richer in species.

\section{Relation of Species Richness with the Level of Abandonment and Current Use}

Our results reflect that the current use did not affect species richness in any of the animal groups studied, but it does affect plants. In general, the works that have analyzed this issue agreed with the intermediate disturbance hypothesis: moderate management would safeguard most potential plant species (Hansson, 2001; Dollman et al., 2007). Gondard et al. (2007) reported similar results in two chestnut woodlands of the Mediterranean region and proposed the maintenance of a mosaic of human-altered woodlands to maintain regional biodiversity. In the chestnut woodlands of England, Mason and McDonal (2002) found greater species richness and a denser vegetative cover two or three years after clearing work was performed, with declining numbers in subsequent years.

On the contrary, the results failed to show an effect by the level of abandonment and current use in the richness of the animal groups studied. In studies concerning the joint effect of the landscape structure and land use on animal richness, group responses were found to vary. Thus, Atauri and de Lucio (2001) showed that the response of species richness to landscape heterogeneity varies depending on the group of species considered. For birds and Lepidoptera, the most important factor affecting the distribution of species richness is landscape heterogeneity, while other factors, such as the specific composition of land use, prove secondary at this scale. On the other hand, amphibian and reptile richness is more closely related to the abundance of certain land-use types. Bailey et al. (2002) correlated bird and mammal distributions to landscape scale measures of fragment distribution, in contrast to butterfly and plant species, which exhibited a stronger correlation to patch- scale measures.

For ants, there is evidence that the internal characteristics of the forest (use) can have more influence than its size or the spatial configuration of the landscape. Thus, for example, Debuse et al. (2007), in a study on ant richness in Australian forests, found that within-patch habitat characteristics explained more than twice the amount of ant species variation attributable to fragmentation and four times the variation explained by habitat loss.

A reasonable explanation could stem from the fact that we are dealing with woodlots that have remained stable over the course of the last three centuries ("seminatural ancient woodlands”) in a setting where traditional agricultural practices are being abandoned. This could help them maintain a high biological richness, regardless of their size and degree of connection with other forest masses (Guitián et al., 2012).

\section{Relation of Species Richness to Forest Maturity}

In the study region, the age of chestnut woodlots proved determinant for vascular-plant richness. Previous studies have reported similar responses and, in some cases, contrary, depending on the type of forest considered (Jacquemin et al., 2001; Widenfalk \& Weslien, 2009 and references therein). Many authors have shown that historical land use may have long-term effects on present-day environmental conditions of forests, hampering or slowing down the colonization processes of many forest plant species. Forest age also represents the colonization period which is directly related to the probability of a species reaching a forest fragment (see references in Jacquemin et al., 2001).

From a different perspective, bird, beetle, and ant richness can not be determined by the degree of forest maturity apparently because the degree of forest maturity may determine species composition and abundance of the different groups more than the number species (see, e.g. Vasconcelos, 1999).

In the case of birds, Ficetola et al. (2006) found that in forest fragments the vertebrate species responded in different ways to perturbations and that, of the bird species studied, only the presence of Parus caeruleus was related to forest maturity. The use of carabids to estimate woodland age was investigated in deciduous woodlands in the UK for a seven-year period (Terrell-Nield, 1999). A significant relationship was found between the age of woodland and the richness of the carabid fauna, but not between the woodland area or circumference and carabid diversity. However, it is important to consider that different results were found according to the food habitats of the different beetle groups (saproxylic vs non-saproxylic).

In conclusion, our results show that vascular plants and animal groups studied respond differently to woodlot size, abandonment level, and woodlot use. This provides substantial evidence that traditional practices do not negatively affect the biodiversity of the chestnut woodlots of the northwestern Iberian Peninsula or favor plant diversity. Therefore, a traditional use of these woodlots may continue to play an important role in maintaining the diversity of plant species in the area.

\section{Acknowledgements}

We would like to express our gratitude to Tania Veiga, Carmen Docampo, Ainhoa Magrach, Alberto Tinaut and Asier R. Larrinaga for their help at various stages of the project. The 
study of the Chestnut Woodlands was funded by the "Dirección Xeral de Investigación of the Xunta de Galicia” through the sectorial research program on Biodiversity. The "Dirección Xeral de Medio Rural” provided the human and material resources for the execution of the cartography of the woodlands.

\section{REFERENCES}

Arnaud, M. Y., Chassany, J. P., Dejean, R., Ribart, J., \& Queno, L. (1997). Economic and ecological consequences of the disappearance of traditional practices related to chestnut groves. Journal of Environmental Management, 49, 373-391. doi:10.1006/jema.1995.0120

Atauri, J. A., \& de Lucio, J. V. (2001). The role of landscape structure in species richness distribution of birds, amphibians, reptiles and lepidopterans in Mediterranean landscapes. Landscape Ecology, 16, 147-159. doi:10.1023/A:1011115921050

Baileya, S.-A., Haines-Young, R. H., \& Watkins, C. (2002) Species presence in fragmented landscapes: Modeling of species requirements at the national level. Biological Conservation, 108, 307-316. doi:10.1016/S0006-3207(02)00119-2

Bastin, L., \& Thomas, C. D. (1999). The distribution of plant species in urban vegetation fragments. Landscape Ecology, 14, 493-507. doi:10.1023/A:1008036207944

Cousins, S. A., \& Aggemyr, E. (2008). The influence of field shape, area and surrounding landscape on plant species richness in grazed ex-fields. Biological Conservation, 141, 126-135. doi:10.1016/j.biocon.2007.09.004

Debuse, V. J., King, J., \& House, A. P. N. (2007). Effect of fragmentation, habitat loss and within-patch habitat characteristics on ant assemblages in semi-arid woodlands of eastern Australia. Landscape Ecology, 22, 731-745. doi:10.1007/s10980-006-9068-0

Dolman, P. M., Hinsley, S. A., Bellamy, P. E., \& Watts, K. (2007). Woodland birds in patchy landscapes: The evidence base for strategic networks. International Journal of Avian Science, 149, 146-160. doi:10.1111/j.1474-919X.2007.00748.X

Dzwonko, Z., \& Loster, S. (1992). Species richness and seed dispersal to secondary woods in Souther Poland. Journal of Biogeography, 19, 195-294. doi:10.2307/2845505

Ficetola, G. F., Sacchi, R., Scali, S., Gentilli, A., De Bernardi, F., \& Galeotti, P. (2007) Vertebrates respond differently to human disturbance: Implications for the use of a focal species approach. Acta Oecologica, 31, 109-118. doi:10.1016/j.actao.2006.10.001

Fujita, A., Maeto, K., Kagawa, Y., \& Ito, N. (2008). Effects of forest fragmentation on species richness and composition of ground beetles (Coleoptera: Carabidae and Brachinidae) in urban landscapes. Entomological Science, 11, 39-48. doi:10.1111/j.1479-8298.2007.00243.x

Gibb, H., \& Hochuli, D. F. (2002). Effects of forest fragmentation on species richness and composition of ground beetles (Coleoptera: Carabidae and Brachinidae) in urban landscapes. Biological Conservation, 106, 91-100. doi:10.1016/S0006-3207(01)00232-4

Gondard, H., Romane, F., Grandjanny, M., Li, J. Q., \& Aronson, J. (2001). Plant species diversity changes in abandoned chestnut (Castanea sativa) groves in southern France. Biodiversity and Conservation, 10, 189-207. doi:10.1023/A:1008997625523

Gondard, H., Romane, F., Santa-Regina, I., \& Leonardi, S. (2006). Forest management and plant species diversity in chestnut stands of three Mediterranean areas. Biodiversity and Conservation, 4, 11291142. doi:10.1007/s10531-004-3103-8

Gondard, H., Santa-Regina, I., Salazar, S., Peix, A., \& Romane, F. (2007). Effect of forest management on plant species diversity in Castanea sativa stands in Salamanca (Spain) and the Cévennes (France). Science and Research Essays, 2, 62-70.

González-Varo, J. P., López-Bao, J. V., \& Guitián, J. (2008). Presence and abundance of the Eurasian nuthatch Sitta europaea in relation to the size, isolation and the intensity of management of chestnut woodlands in the NW Iberian Peninsula. Landscape Ecology, 23, 7989. doi:10.1007/s10980-007-9166-7

Gotelli, N. J., \& Colwell, R. K. (2001). Quantifying biodiversity: Procedures and pitfalls in the measurement and comparison of species richness. Ecology Letters, 4, 379-391.

doi:10.1046/j.1461-0248.2001.00230.x

Guitián, J., Guitián, P., Magrach, A., Docampo, C., Domínguez, P., \& Guitián, L. (2012). Effect of management and spatial characteristics on plant species richness of Castanea sativa Mill. Woodlots in the NW Iberian Peninsula. Journal of Forest Research, 17, 98-104. doi:10.1007/s10310-011-0261-X

Hannson, L. (2001). Traditional management of forests: Plant and bird community responses to alternative restoration of oak-hazel woodland in Sweden. Biodiversity and Conservation, 10, 1865-1873. doi:10.1023/A:1013125611492

Heck, K. L., Van Belle, G., \& Simberloff, D. (1975). Explicit calculation of rarefaction diversity measurement and the determination of sufficient sample size. Ecology, 56, 1459-1461. doi:10.2307/1934716

Jacquemin, H., Butaye J., \& Hermy, M. (2001). Forest plant species richness in small, fragmented mixed deciduous forest patches: The role of area, time and dispersal limitations. Journal of Biogeography, 28, 801-812. doi:10.1046/j.1365-2699.2001.00590.x

Karr, J. R. (1971). Structure of avian communities in selected Panama and Illinois habitats. Ecological Monographs, 41, 207-233. doi:10.2307/1942366

Konstantinidis, P., Tsiourlis, G., Xofis, P., \& Buckley, G. P. (2008) Taxonomy and ecology of Castanea sativa Mill. Forest in Greece. Plant Ecology, 195, 235-256. doi:10.1007/s11258-007-9323-8

Mason, C., \& MacDonald, S. M. (2002). Responses of ground flora to coppice management in English woodland-A study using permanent quadrants. Biodiversity and Conservation, 11, 1773-1789. doi:10.1023/A:1020395014155

Peltzer, D. A., Bast, M. L., Wilson, S. D., \& Gerry, A. K. (2000). Plant diversity and tree responses following contrasting disturbances in boreal forest. Forest Ecology and Management, 127, 191-203. doi:10.1016/S0378-1127(99)00130-9

Petit, S., Griffiths, L., Samrt, S. S., Stuart, R. C., \& Whight, S. M. (2004). Effect the area and isolation of woodland patches on herbaceous plant species richness across Great Britain. Landscape Ecology, 19, 463-471. doi:10.1023/B:LAND.0000036141.30359.53

Pitte, J. R. (1986). Terres de castanide. Hommes et paysages du châtanier de l'Antiquité à nous jours. Paris: Fayard.

Rey Benayas, J. M., Martins, A., Nicolau, J. M., \& Schulz, J. J. (2007). Abandonment of agricultural land: An overview of drivers and consequences. CAB Reviews, 2, 1-14. doi:10.1079/PAVSNNR20072057

Ribera, I., Dolèdec, S., Downie, I. S., \& Foster, G.N. (2001). Effect of land disturbance and stress on species traits of ground beetle assemblages. Ecology, 82, 1112-1129. doi:10.1890/0012-9658(2001)082[1112:EOLDAS]2.0.CO;2

Roberts, M. R., \& Gilliam, F. S. (1995). Patterns and mechanisms of plant diversity in forested ecosystems: Implications for forest management. Ecological Applications, 5, 969-977. doi:10.2307/2269348

Rodríguez-Guitián, M. (2004). Aplicación de criterios botánicos para a proposta de modelos de xestión sustentable das masas arborizadas autóctonas de subsector galaico asturiano septentrional. Doctoral Thesis, Santiago: University of Santiago.

Rodríguez-Guitián, M., Rigueiro, A., Real, C., Blanco, J., \& Ferreiro da Costa, J. (2005). El hábitat “9269 Bosques de Castanea sativa” en el extremo noroccidental ibérico: Primeros datos sobre la variabilidad florística de los “soutos”. Bulletin de la Societé d'Historie Naturelle de Toulouse, 1441, 75-81.

Romane, F., Gondard, H., Grandjanny, M., Grossmann, A., Renaux, A., \& Shater, Z. (2001) Measuring and managing plant species diversity in the chestnut (Castanea sativa Mill.) ecosystems of the Cevennes. Forest, Snow and Landsape Research, 76, 493-497.

Taboada, A., Kotze, D. J., \& Salgado, J. M. (2004). Carabid beetle occurrence at the edges of oak and beech forests in NW Spain. European Journal of Entomology, 101, 555-563.

Terrell-Nield, C. (1999). Is it possible to age woodlands on the basis of their carabid beetle diversity? Journal of Entomology, 109, 136-145.

Vasconcelos, H. L. (1999). Effects of forest disturbance on the structure of ground-foraging ant communities in central Amazonia. Biodiversity and Conservation, 8, 409-420. doi:10.1023/A:1008891710230

Veldkamp, A., \& Lambin, E. F. (2001). Predicting land-use change. Agriculture, Ecosystems and Environment, 85, 1-6. 
doi:10.1016/S0167-8809(01)00199-2

Widenfalk, O., \& Weslien, J. (2009). Forest ecology and management plant species richness in managed boreal forests-Effects of stand succession and thinning. Forest Ecology and Management, 257, 1386-1394. doi:10.1016/j.foreco.2008.12.010

\section{Appendix I}

\section{Bird Species}

Aegithalos caudatus

Anthus trivialis

Buteo buteo

Carduelis chloris

Certhia brachydactyla

Columba palumbus

Corvus corone

Cuculus canorus

Dendrocopos major

Emberiza cia

Erithacus rubecula

Fringilla coelebs

Garrulus glandarius

Lanius collurio

Motacilla alba

Muscicapa striata

Oriolus oriolus

Parus ater

Parus caeruleus

Parus cristatus

Parus major

Phoenicurus phoenicurus

Phylloscopus bonelli

Phylloscopus ibericus

Pica pica

Picus viridis

Prunella modularis

Pyrrhula pyrrhula

Regulus ignicapillus

Serinus serinus

Sitta europaea

Streptopelia turtur

Sturnus unicolor

Sylvia atricapilla

Troglodytes troglodytes

Turdus merula

Turdus philomelos

Turdus viscivorus

\section{Ant species}

Aphaenogaster sp.
Formica fusca

Formica lugubris

Formica rufa

Lasius brunneus

Lasius flavus

Lasius fuliginosus

Leptothorax sp

Myrmica ruginodis

Tapinoma erraticum

\section{Beetle Species}

Acalles sp.

Agathidium escorialensis

Amthobium sp.

Anchonidium unguiculare

Anthous (sp1, sp2, sp3)

Aphodius fossor

Archicarabus steuartii

Blaps sp.

Bolitobius castaneus

Brachinus crepitans

Brachyderes lusitanicus

Bryaxis sp.

Caenopsis waltoni

Calathus (Neocalathus) rotundicollis

Carabus oreocarabus amplipennis

Catops grandicollis

Chasmatopterus sp.

Choleva sp.

Chrysocarabus lateralis lateralis

Criptophagus puncipennis

Criptophagus setulosus

Cychrus spinicollis spinicollis

Dactylosternum abdominale

Dacne bipustulata

Dermestes haemorrhoidales

Dienerella (Cartoderema) clathrata

Drusilla canaliculata

Falagriusa thoracica

Galeruca tanaceti

Geotrupes stercorarius

Hylis olexai
Leistus oopterus

Lordithon exoletus

Mastigus prolongatus

Megasternun concinnum

Mesocarabus macrocephalus

Microplepus staphylinoides

Microscydmus (Minimus) minimus

Mycetoporus rufescens

Necrophorus vespilloides

Nicrophorus sepultor

Niptus sp.

Nosodendron sp.

Nothiophilus quadripunctatus

Ocypus (Ocypus) olens

Ocypus pecipennis

Onthophagus taurus

Ontophylus punctatus

Orchesia sp.

Orobitis cyanea

Othius punctulatus

Pachytychius sparsutus

Paleonthophagus vacca

Parabolitobius inclinans

Paralister stercorarius

Phosphuga atrata

Platydracus stercorarius

Pselaphus heisei

Pterostichus cantabricus

Ptinus fur

Ptomophagus (P.) tenuicornis

tenuicornis

Quedius latinus

Sciodrepoides watsoni

Silpha sp.

Speonemadus vandalitiae

Steropus gallega

Strophosoma erinaceus

Strophosoma sp.

Strophosoma umbilicatum

Trechus optusus

Triodonta sp. 